\title{
Studies on luciferin-luciferase ATP assay in plants (etiolated wheat germs, and bean leaves)
}

\author{
A. BARBARO and S. ROŻEK \\ Department of Plant Physiology, Institute of Biology of Crops Planits, \\ Academy of Agriculture, Cracow \\ (Received: January 9, 1975)
}

\begin{abstract}
For ATP determination by the method of bioluminescence apparatus of home production was adapted from the equipment available in any isotope laboratory. The measurement error did not exceed 1.5 per cent. Methodical experiments concerned the choice of the extraction, fixation and storage methods of plant material for determination at the given moment of the amount of ATP in the tissues, unchanged by the analyitical procedure. The highest ATP amounts were recovered by extraction with perchloric acid at high $(25 \%)$ concentrations of the tissue in the homogenate. The best way of fixation of the material for later analyses was found to be freezing of ready extracts. Lyophilization and freezing of the plant material caused a several-fold decrease of the ATP level in the tissues. These results suggest the necessity of working in conditions of low temperature during the entire analytical procedure and strict observation of time limitation.
\end{abstract}

\section{INTRODUCTION}

ATP is an essential compound in the energetic metabolism of living organisms, therefore the need arises of its quantitative determination. This substance extracted from living material is extremely labile and rapidly decomposes. The methods of purification (activated carbon, ion exchangers) and separation of free nucleotides such as paper chromatography (Bieleski, Young, 1963; Hurlbert et al., 1965; Hurwit $z$ et al., 1957), thin-layer chromatography, paper electrophoresis and column chromatography on ion exchangers $\mathrm{Hurlbert}$ et al., 1965; $\mathrm{Kul}$ a y e $\mathrm{v}$ et al., 1971) cause considerable losses in ATP.

The necessity of preliminary separation of nucleotides from the associated compounds leads to a loss of about 50 per cent of nucleotide L a- 
dy g in a and $\mathrm{Rubin}$, 1971). An additional difficulty in plant material is due to phenol compounds which have $R_{f}$ values close to those of ATP. Their removal from a nucleotide mixture requires the application of several separation techniques and must cause ATP breakdown. These difficulties and losses have been confirmed in the present studies. In preliminary trials of adenine nucleotide determination by the spectrophometric method after their separation by paper chromatography or on Sephadex much smaller ATP amounts were found than when the further described method of bioluminescence is used. In view of the instability of phosphate bonds in ATP, it is very important to perform the determinations of this compound in the shortest possible time and by simplest analytical methods. These requirements are fulfilled by the enzymatic methods (A d a m, 1962; Lamprecht and Trautschold, 1962). Most sensitive and simplest from among them is the bioluminescence method ( $\mathrm{Str}$ e hler, 1962). As compared with this method chemical and even other enzymatic ones require much higher concentrations of ATP. The minimal concentration in chemical methods (e.g. colorimetric) is $10^{-1} \mathrm{M}$, and when ion exchangers are used, $3 \times 10^{-2} \mathrm{M}$; in enzymatic methods it is in the case of hexokinase $10^{-3} \mathrm{M}$ ( $\mathrm{L} \mathrm{a} \mathrm{mprecht}$ and $\mathrm{Trautschold}$, 1962) and for phosphoglycerate kinase $10^{-9} \mathrm{M}$ (A d a m, 1962). It is possible, however, by the bioluminescence method to determine on special precise apparatus even trace amounts of ATP of the order of $10^{-20} \mathrm{M}$ (S ł a w in s ki, 1973), thus it is at least a million times more sensitive than other methods. It also gives, owing to the extremely high specificity towards the substrate, the best reproducible, accurate and reliable results. Another of its advantages is the possibility of determination of the remaining adenin nucleotides (e.g. Holmsen et al., 1966).

It is in general not necessary in biological investigations to perform determinations of such high precision. In living organisms the ATP content is rather high, so that for obtaining measurable ATP concentrations adjusted to the separation possibilities of the apparatus within the limits of $10^{-6} \mathrm{M}$, extracts of $1 \mathrm{~g}$ of fresh wheat germs had to be diluted as much as $200-500$-fold. Similarly, even in sea water from various depths this compound was found in concentrations of the order of $10^{-4} \mu \mathrm{g}(\mathrm{H}$ ol m- Hansen, and Booth 1966), and in algae ATP was determined in concentrations of $10^{-6}$ to $10^{-7} \mathrm{M}$ ( $\mathrm{J} \circ \mathrm{h} \mathrm{n}, 1970$ ). When, however, ATP is determined in a single cell or in tissue fragments, more precise measurements are necessary: for instance in crab muscles ATP concentration is of the order of $5 \times 10^{-12}$ or even $3 \times 10^{-15} \mathrm{M}$ ( $\mathrm{Lin}$ and $\mathrm{Coh}$ en, 1968) and in the root caps of maize $10^{-9} \mathrm{M}$ ( $\left.\mathrm{J} \circ \mathrm{h} \mathrm{n}, 1970\right)$. Hence numerous methodical studies deal with the problem of more refined apparatus which would increase the sensitivity and rapidity of measurement (Stanley and Williams, 1969; Dufrense and Gitelman, 1970; Holmsen et al., 1966). 
In other papers much attention has been devoted, as regards the above mentioned method, to the influence of ions and organic compounds interfering with ATP as well as to the dependence of luminescence on pH (McElroy and Strehler, 1969; Holmsen et al., 1966; Stanley and Williams 1969).

The method of bioluminescence, although it has many advantages and is commonly used in biochemical and physiological investigations (C o nkell and Polglase, 1970; De Greef et al., 1971; John, 1970; Li ubimova et al., 1964; Lin and Cohen; 1968, Loercher and Liverman, 1964; McDonald and Guin, 1969; Penth and W eig 1, 1971; Sha effer et al., 1972) has only been seldom applied in Poland, perhaps on account of lack of adequate measuring apparatus.

The aim of the present methodical studies was a trial of adaptation of home-made apparatus available in any isotope laboratory to bioluminescence measurent. In the course of the work the need arose of more detailed investigations, in order to establish the conditions for plant material preparation and extraction and for ATP determination.

\section{THE BIOLUMINESCENCE REACTION}

Light emission has been noted in numerous living organisms. This property has been observed in luminescent bacteria (Achromobacter fischeri) molluses (Pholosdoctiglus), fungi (Opholi flarida), grubs (Odontosylis, Renilla reniformis), crustaceans (Cipridiana), fishes (Apodon), fireflies (Luciola mingrelica, Photonus pyralis) and others. In most of these luminescent organisms luciferin as active substrate and the enzyme luciferase catalysing the reaction are present. Phosphate labile groups derived from ATP are also involved in the luminescence reaction.

The method of bioluminescence was applied for the first time in vitro for ATP determination by Strehler and Totter in 1952, on the basis of the discovery of M c Elroy (1947) that aqueous extracts from luminescent firefliies (Photinus pyralis) may be induced to luminescence by the addition of ATP, when their own light emission has ceased. The principle of the method consists in measurement of emitted light. The reaction may be expressed according to Strehler's diagram (1962) as follows

$$
\begin{aligned}
& \text { ATP }+ \text { luciferin } \underset{\text { luciferase }}{\longrightarrow} \text { adenyl-luciferin }+ \text { pyrophosphate } \\
& \text { adenyl-luciferin } \stackrel{\mathrm{Og}_{2}}{\longrightarrow} \text { adenyl-oxyluciferin }+\mathrm{H}_{2} \mathrm{O}+\text { light. }
\end{aligned}
$$

Thus, in the presence of ATP and of magnesium ions the enzyme of the insect, luciferase, catalyses luciferin oxidation so that the latter becomes 
an excited molecule, and returning to normal state emits light. When luciferin-luciferase are in excess, the relation between light emission and ATP concentration is directly proportional.

\section{MATERIAL, METHODS AND RESULTS}

\section{Measuring apparatus}

For serial ATP measurement by the bioluminescence method various types of photomultipliers are used $(\mathrm{Holm}-\mathrm{Hansen}$ and $\mathrm{Booth}$, 1966; Lin and Cohen, 1968; Ladygina and Rubin, 1971; Miliekhina, and Rakhlieyeva, 1970; Strehler, 1962). Spectrophotometers equipped with photomultipliers as for instance the Beckmann spectrophotometers were also used.

The high prices and restrictions in purchase of equipment for foreign currency prompted the authors to check the adaptability of home-produced apparatus in this respect. Apparatus produced by the Establishment of Nuclear Appliances "Polon", intended for measurement of low-frequency beta and gamma radiation was tested. The measuring set (Fig. 1) included:

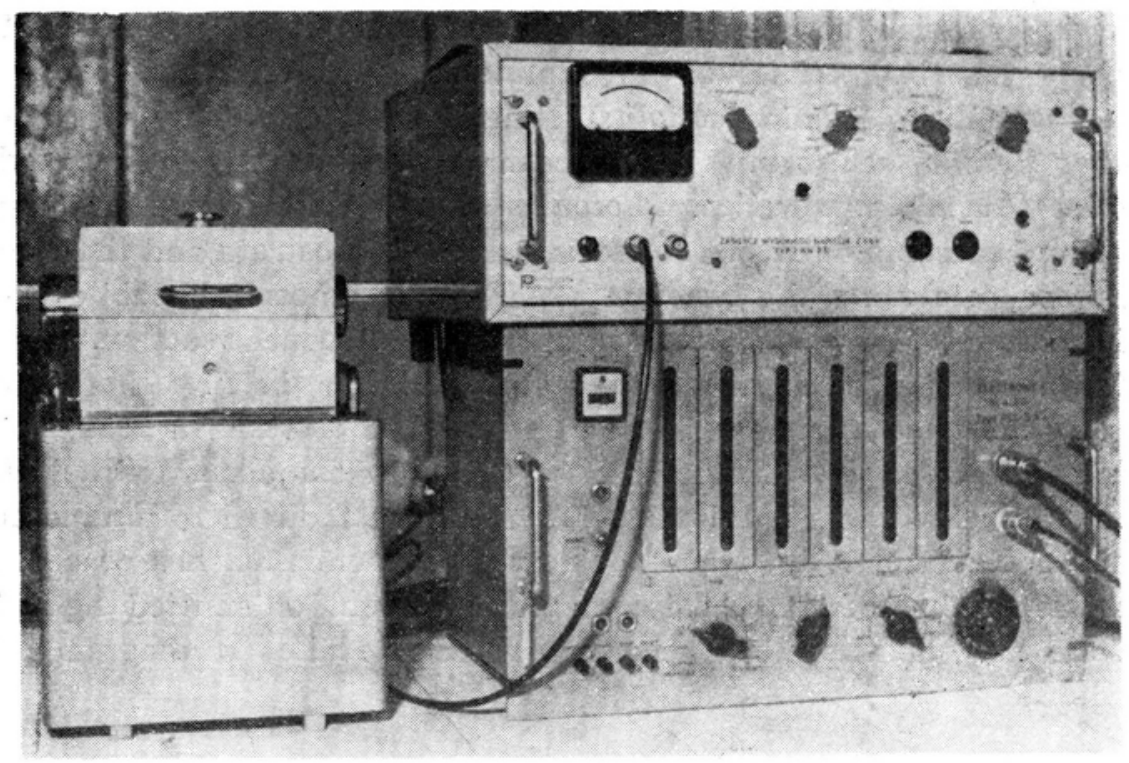

Fig. 1. Set-up for bioluminescence measurement

(a) a scintillating set-up type USB-2 (photomultiplier EMI) with a device for water temperature stabilization,

(b) type $\mathrm{ZWN}-2,5$ high voltage feeder,

(c) an electron type KEL-5a scaler equipped with a timer and a discriminating device for extinguishing the photomultiplier noises. 
Optimal parameters for measurement were established at $850 \mathrm{~V}$ in the feeder, and a discrimination threshold at which the pulse frequency did not exceed $10 / 30$ s. For establishing the suitable voltage, that is such which if exceeded causes no more a proportional increase of pulse frequency, a series of photomultiplier background measurements was performed with increasing voltage and with discrimination threshold equal to zero. The fact was taken into account that the voltage rise produces a proportional increase of the number of pulses emitted by the photomultiplier only within certain limits of voltage. After establishing optimal voltage, the noises were extinguished by adjustment of the discriminator.

\section{Standard curve}

The suitability of the apparatus for bioluminescence measurement was checked by measuring the dependence of emitted light intensity on ATP concentration. This relation was plotted on a graph (Fig. 2). The standard curve was traced for standard solutions prepared freshly each time before measurement from 1-mg portions of ATP available in separate vials

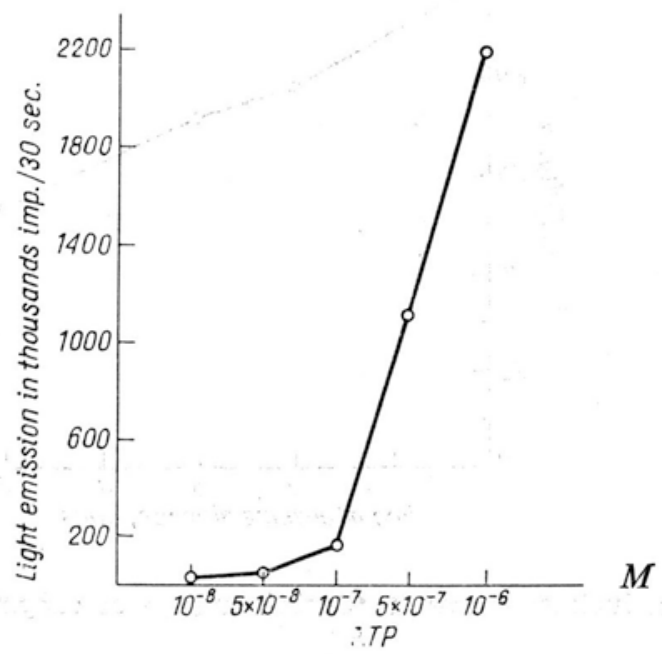

Fig. 2. Bioluminescence versus ATP concentration

(Sigma U.S.A.). The purity of the preparation was checked by paper chromatography and the percentual ATP content by the spectrophotometric method. The data agreed with the firm's attestation (99\% ATP without trace of contamination). The curve segment, along which a slight increase in ATP content corresponds to a considerable intensification of light emission, lay in our measurement system in the ATP concentration range $10^{-7}-10^{-6} \mathrm{M}$. This is in agreement with the character of the bio- 
luminescence reaction in the luciferin-luciferase system in which the $\mathrm{Michaelis}$ constant for ATP is $5 \times 10^{-5} \mathrm{M}$ at $\mathrm{pH}$ 7.4. In further methodical trials of measurements of the quantity of ATP it was endeavoured to maintain the concentration of this compound within the established limits. By constructing the standard curve the experimenter gains orientation as to the range of most suitable concentrations for ATP determination at the given parameters of the apparatus and activity of the enzymatic extract. This curve prepared once cannot be used for reading the ATP quantities according to the intensity of light emission, since the enzymatic extracts from the luminescent organs of fireflies differ in activity. The latter depends also on the kind of buffer used ( $\mathrm{L}$ i n and $\mathrm{Coh}$ en, 1968). This reservation is not so important if we are dealing with a purified luceferin-luceferase complex which may be purchased from Sigma. Since in the present work we used crude preparations, a fresh enzymatic extract and a standard ATP solution were prepared for each series of analyses, the results serving for further conversions of the ATP

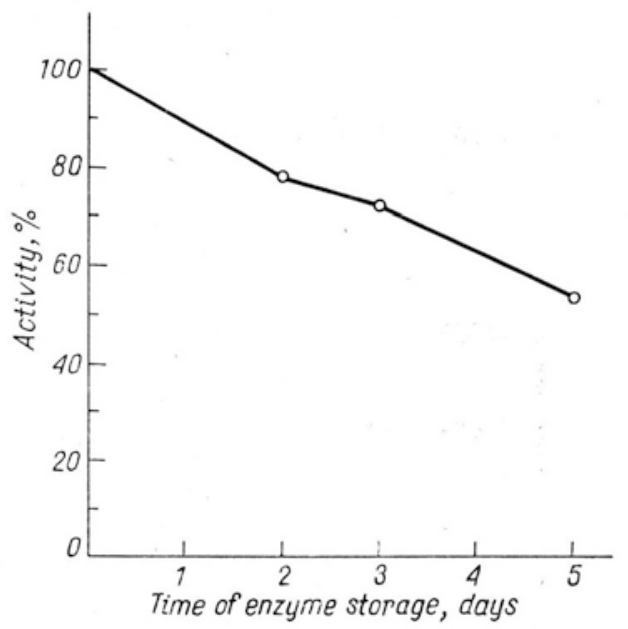

Fig. 3. Changes in luciferase activity during storage of enzymatic extract at $-5^{\circ} \mathrm{C}$

level in the sample examined. In view of the fact that the reaction mixture is very sensitive to the sample composition as regards luciferase inhibitors and ions or compounds stimulating this enzyme (M c Elroy, and Strehler, 1949), internal standards were sometimes prepared (J ohn, 1970; Miliekhina and Rakhlieieva, 1970).

For ATP measurements the luminescence of the firefly Photinus pyralis (purchased from SIGMA, U.S.A. - FFT Firefly lanterns desiccated tails) was utilized. Enzymatic luciferin-luciferase extract was prepared from them according to S tre hle r and T ot t e r (1952): $50 \mathrm{mg}$ of lyophi- 
lized firefly abdomens was ground in a frozen mortar with $1 \mathrm{ml}$ of $0.1 \mathrm{M}$ arsenate buffer, $\mathrm{pH} 7.4$ for $8-10 \mathrm{~min}$. The homogenate was quantitatively transferred to a centrifuge test tube with threefold washing of the mortar with $0.5 \mathrm{ml}$ buffer each time. The test tubes were lightly shaken for $1 \mathrm{~min}$ and then centrifuged in the cold for $5 \mathrm{~min}$ at $8000 \mathrm{~g}$. The supernatant was decanted into a vial and $50 \mathrm{mg} \mathrm{MgSO}_{4}$ was added. This extract from the luciferin-luciferase complex was left to stand in a refrigerator for $4 \mathrm{~h}$ until it ceased to luminesce (i.e. till endogenous breakdown of firefly ATP). Before starting ATP determination, the primarily obtained enzymatic extract was diluted to $12.5 \mathrm{ml}$ and poured into measuring flasks, $0.4 \mathrm{ml}$ into each, and stored before measurement in darkness at room temperature. The extract prepared may be used for several days for bioluminescence measurement. According to the recommendations of $\mathrm{Strehler}$ and Totter (1952) it should be stored at $4^{\circ} \mathrm{C}$. Extracts kept in frozen state loose a great deal of luciferase activity (L a d y g i n a and Rubin, 1971; Strehler, 1962). In the present experiments after $\bar{j}$ days of storage at $-5^{\circ} \mathrm{C}$, a decrease in luminescence by 50 per cent (Fig. 3) was noted. Thus, under such conditions there is a risk that the amount of enzyme may be insufficient in proportion to the substrate.

\section{Measuring procedure}

Standard ATP solution or respectively diluted plant extract were poured in 1-ml doses from a burette into the measuring flask stirred rapidly and placed in a light-tight chamber over the photosensitive layer of the photomultiplier. Fifteen seconds after combining the solution to be measured with the enzymatic extract, the pulse counter was switched on. Emission was measured for $30 \mathrm{~s}$ (according to the rate of the clock device of the counter). In order to obtain a uniform light dispersion it is necessary to use flasks of identical surface area and bottom thickness. The mass-manufactured vessels supplied as equipment with the apparatus do not fulfill these requirements, it was, therefore, necessary to have them made to order A scintillator liquid silicon oil was used.

\section{Plant material}

In further methodical tests 1-g samples of etiolated wheat germs separated frcm the endosperm were used. In order to dispose of uniform material, the caryopses were germinated each time under the same temperature and moisture conditions for the same time period. The reproducibility of results, when observing the methodical recommendations, was also checked on green plant material (bean leaves). 
The high lability of ATP mentioned at the beginning and the resulting possibility of its decomposition during the measurement procedure prompted us to detailed investigations on the influence of the mode of extraction, tissue concentration in the homogenate and various methods of fixation and storage of plant material on the determination of ATP.

\section{Influence of extraction methods on ATP recovery}

Several methods of ATP extraction most commonly used in nucleotide isolation were examined in this respect: extraction with $1.5 \mathrm{~N}$ perchloric acid (PCA), with 10 per cent trichloroacetic acid (TCA) and with $0.02 \mathrm{M}$ Tris- $\mathrm{HCl}$ buffer, $\mathrm{pH} 7.4$ in the hot. The results are shown in Fig. 4. Extraction with $1.5 \mathrm{~N} \mathrm{PCA}$ and 10 per cent TCA gave similar ATP recovery, but in the former case reproducibility was better. On the other hand, when Tris buffer was used, the ATP amounts obtained were three times lower with low reproducibility of results.

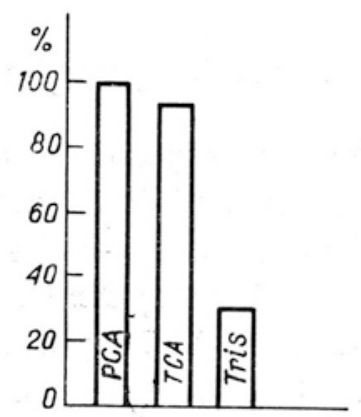

Fig. 4. Comparison of effectiveness of ATP extraction from wheat germs with $1.5 \mathrm{~N}$ PCA, $10 \%$ TCA and Tris buffer (means of 6 extractions as per cent of compound revealed after extraction with $\mathrm{PCA}$ )

The condition for extraction of the whole ATP amount for determination of its content in tissue at the given moment, is the use of an appropriate reagent which would warrant immediate killing of the cells with complete protein precipitation and inactivation of enzymes of the ATPase group. The use of boiling Tris buffer caused considerable losses reaching as much as 90 per cent of ATP, probably owing to insufficently rapid inactivation of the enzymes. Similar results of water extraction from animal material are reported by $\mathrm{Ch}$ a s e (1960). $\mathrm{Hol} \mathrm{m}-\mathrm{H}$ a $\mathrm{n}$ s e $\mathrm{n}$ and B o o th (1966) in their studies on phytoplankton, however, when determining ATP mostly in unicellular organisms, found extraction in the hot Tris buffer to be efficient. It is possible that in this case penetra- 
tion of hot buffer was extremely rapid so that the cells were killed immediately, but this does not occur in the same way in a large vegetal mass.

At first a PCA solution was prepared in 70 per cent ethanol. This, however, is not recommendable in the bioluminescence method, although it is used commonly in extraction of free nucleotides. It is namely, necessary in this case to evaporate the extract until the alcohol inhibiting luciferase activity is completely distilled off ( $\mathrm{H}$ ol m s e $\mathrm{n}$ et al., 1966). Almost complete extinction of luminescence was noted in our experiments in the presence of ethanol in the extract. Besides, the rise of temperature necessary for evaporation causes considerable loss in ATP.

In further methodical studies an aqueous $1.5 \mathrm{~N}$ PCA solution was used, neutralized immediately before measurement with $5 \mathrm{~N} \mathrm{KOH}$ to $\mathrm{pH}$ 7.4.

\section{Extraction yield}

For checking how much ATP passes from the tissue into solution in the first and subsequent extractions, the procedure was repeated and ATP was determined in the same plant material sample three times. It was found that practically the entire ATP content passes into the first extract, the further ones only contain trace amounts (Table 1).

Table 1

Comparison of recovery $(\%)$ in successive ATP extractions from the same material

\begin{tabular}{c|c|c}
\hline $\begin{array}{c}\text { Successive } \\
\text { extraction }\end{array}$ & $\begin{array}{c}\text { No. of impulses } \\
\text { per } 30 \mathrm{sec}\end{array}$ & $\%$ \\
\hline I & 2034000 & 100 \\
II & 154 & 0.0076 \\
III & 30 & 0.0015 \\
\hline
\end{tabular}

These results allow to limit the procedure to a single extraction. In view of the possibility of ATP degradation by way of autohydrolysis, this conclusion is very important for obtaining exact results, owing to the shortened time of analysis. On the other hand, it gives the experimenter the possibility of performing more determinations within the same time.

Influence of tissue concentration in homogenate on efficiency of ATP extraction

ATP was extracted at 2.8, 10 and 25 per cent tissue concentrations. The results are shown in fig. 5 . The greatest ATP amounts could be extracted at 25 per cent tissue concentration, thus when it was highest. This finding is interesting when confronted with the results of $\mathrm{R}$ o o d y n 
(1968) who, on the contrary, recovered large quantities of free nucleotides at lower tissue concentrations (i.e. when the homogenates were more diluted). It would seem, therefore, that the results of Roodyn were due to changes in the content of the remaining free nucleotides, since they cannot be attributed to ATP. Perhaps the better efficiency of extraction

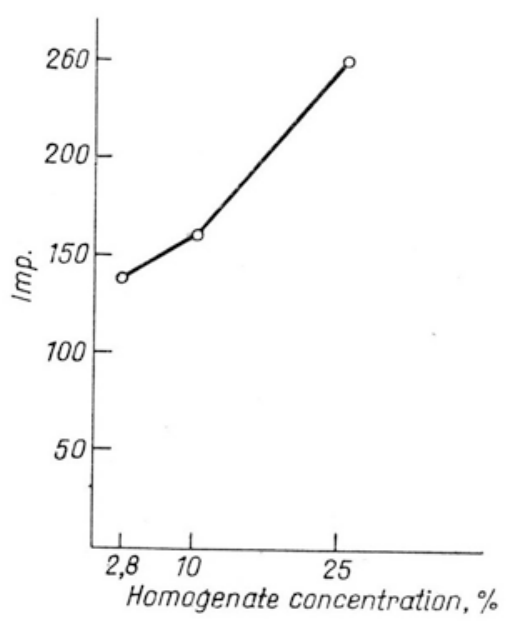

Fig. 5. Influence of tissue concentration in homogenate on ATP extraction efficiency (thousands of pulses per $5 \mathrm{mg}$ of tissue)

at higher homogenate concentration might be explained by the stability of ATP in concentrated solution; in other experiments it was, namely, found that ATP decomposition occurs much quicker in diluted solution than at higher concentrations. Hydrolytic ATP breakdown in our homogenates was also found to be slower than in aqueous solution. This would suggest some protective properties of the homogenate in respect to ATP.

Influence of fixation and storage of material for analysis

In numerous experiments it is necessary to put off analysis after sample collection. In such cases various methods of fixation of biological material have to be applied. The basic method in biological studies is lyophylization ensuring an unchanged biochemical composition and cell structure and the possibility of recovery of the tissue to the initial state of definite physiological activity. The influence of 3 ways of fixation and storage of plant material on the ATP content in etiolated wheat germs was tested:

1. lyophilization of isolated germs,

2. freezing of germs at $-28^{\circ} \mathrm{C}$,

3. freezing of extract at $-28^{\circ} \mathrm{C}$. 
For lyophilization an apparatus built in our Department was used (W o j t a s z e k 1959) and apparatus of The Virtis Co. Inc. Gardiner, N. Y. U.S.A. (type Freeze dryer). The ATP content was compared in freshly prepared extract after germ separation from endosperm and extract from germs fixed after isolation. The uniformity of the outsed material was ensured by taking each time simultaneous samples. Lyophilization in our apparatus was found to cause a fivefold, and in the American apparatus a tenfold fall of the ATP level. Reproducibility of measurement was, however, higher in the later case (Fig. 6). Differences in the influence of

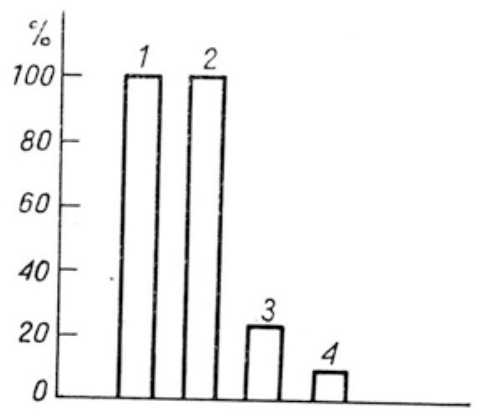

Fig. 6. Comparison of ATP content per weight unit of plant mass (etiolated wheat germs) in variously fixed material. ATP level in fresh extract assumed as 100 .

Bars: 1 - Fresh extract, 2 - frozen extract $\left(-28^{\circ} \mathrm{C}\right.$ for $\left.48 \mathrm{~h}\right), 3$ - extracts from lyophilized plants (lyophilized in home built apparatus), 4 - extracts from plants lyophilized (in Freeze Dryer ,The Virtis")

lyophilization on ATP decomposition may be explained by the different construction of the apparatus. The time of exposure to low temperature was ideally equal for all samples in the American apparatus, whereas in ours freezing occurred quicker, but was less uniform owing to the localization of the samples in the freeze-dry chamber at various distances from the cooling device. These results distinctly point to ATP breakdown during lyophilization and lead to the conclusion that investigations on lyophilized material can only give relative ATP values, while the experimenter is unable to determine the actual amount of the nucleotide. This should be borne in mind, all the more, since in the available literature no reservations concerning lyophilization of the material for ATP determination have been found.

In germ fixation by freezing at $-28^{\circ} \mathrm{C}$ large loss in ATP also occur. At this temperature external symptoms of freezing may be observed almost immediately. Nevertheless, a manifold fall of the ATP level was noted after 48 and $24 \mathrm{~h}$ and even after $1 \mathrm{~h}$ (Fig. 7). From the point of view of ATP stability, storage of the germs at $+4^{\circ}$ and $+24^{\circ} \mathrm{C}$ (for $1 \mathrm{~h}$ ) was less detrimental, causing a reduction of ATP by only 30 per cent (Fig. 8). It is possible that other methods of freezing such as the use of liquid nitrogen or solid $\mathrm{CO}_{2}$ would be more suitable, since freeze-drying 
of histological preparations at $-80^{\circ} \mathrm{C}$ ( $\mathrm{H}$ a $1 \mathrm{~b} \mathrm{~h}$ u r b e r et al., 1970) caused only a 10 per cent loss in ATP. It would seem that freezing of all cells in this case occurs immediately and defreezing only during extraction. These methods have, however, at present not been tested.

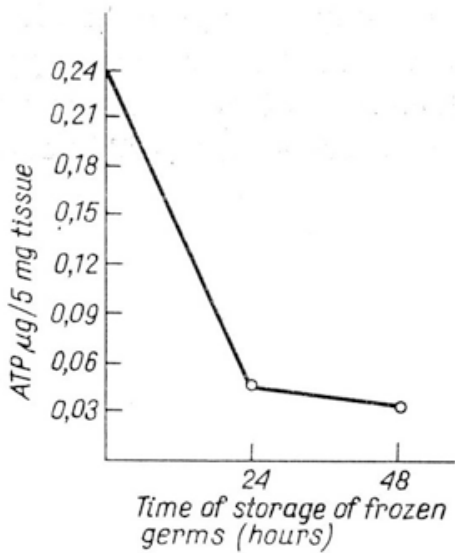

Fig. 7.

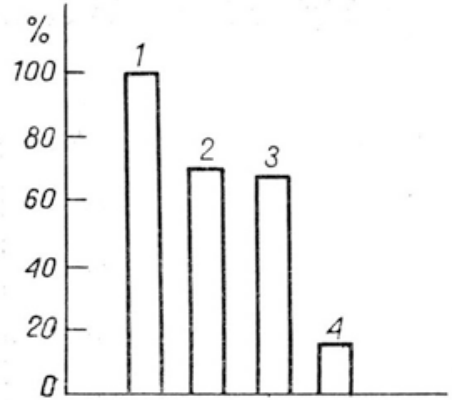

Fig. 8.

Fig. 7. Fall of ATP level in germs during freezing at $-28^{\circ} \mathrm{C}$

Fig. 8. Influence of storage temperature of germs for $1 \mathrm{~h}$ on ATP content. ATP level in extracts from germs prepared immediately after their isolation assumed as 100 .

Bars: 1 - extracts from germs immediately after isolation, 2 - extracts from germs stored at $20^{\circ} \mathrm{C}, 3-$ extracts from germs stored at $4^{\circ} \mathrm{C}, 4-$ extracts from germs stored at $-28^{\circ} \mathrm{C}$

It was found, on the other hand, that a very good way of preserving the material for later analyses of ATP is freezing of ready extracts at $-28^{\circ} \mathrm{C}$. Their storage in these conditions for $24,48 \mathrm{~h}$ and longer did not cause any loss in ATP (Fig. 5). It is not clear why the ATP level fell when the tissue was frozen at $-28^{\circ} \mathrm{C}$, whereas the same did not occur when extracts were frozen to this temperature. The considerable loss in ATP when freezing was insufficiently rapid, as was probably the case at $-28^{\circ} \mathrm{C}$, might be explained by the fact that damage caused by low temperature to the cytoplasmic membrane releases the ATPases bound with them, which rapidly decompose ATP. On the other hand, the lack of change in the ATP level in frozen extracts as compared with fresh ones may be due to the removal of the ATPases from the medium at the moment of extraction by the denaturating agent precipitating protein such as PCA used in the present experiments. The action of low temperature was limited here to the inhibition of ATP autohydrolysis. L o w r y et al. (1964) also observed an important decrease in ATP induced by a rise of temperature lasting several seconds during extraction of this compound. It should be stressed that the commonly applied rule of working at low temperature in analyses of acid-soluble phosphorus compounds 
(Le Page and Umbreit, 1948) is particularly important in the case of ATP determination.

On the basis of methodical studies ATP extraction from etiolated wheat germs and bean leaves was run as follows: a 1-g weighed sample of plant material was ground in a mortar with $1.5 \mathrm{~N} \mathrm{HClO}_{4}$ added, the solid parts were centrifuged off in a cooled centrifuge, the supernatant was adjusted with $5 \mathrm{~N} \mathrm{KOH}$ to $\mathrm{pH}$ 7.4. The homogenate obtained after centrifuging off the potassium perchlorate precipitate was diluted 20 -fold and just before measurement 200-fold as compared with the outset fresh material in the case of leaves and even 500-fold in the case of germs.

Table 2

ATP $/ 5 \mathrm{mg}$ fresh leaf weight (micrograms)

\begin{tabular}{l|c|c|c|c|c}
\hline No. & Measurement & No. & Measurement & No. & Measurement \\
\hline 1. & 0.4320 & 6 & 0.4322 & 11 & 0.4364 \\
2. & 0.4305 & 7 & 0.4365 & 12 & 0.4442 \\
3. & 0.4361 & 8 & 0.4419 & 13 & 0.4400 \\
4. & 0.4408 & 9 & 0.4488 & 14 & 0.4368 \\
5. & 0.4433 & 10 & 0.4544 & 15 & 0.4290 \\
\hline
\end{tabular}

Arithemetic mean $0.4389 \mu \mathrm{g}$ ATP

Error of arithmetic mean $0.0018 \mu \mathrm{g}$ ATP

Variability coefficient $1.5452 \%$

The procedure in preparation of the enzymatic extract is described in the paragraph "Standard curve" and bioluminescence measurement in the paragraph "Description of measuring procedure".

In Table 2 results of determination of ATP content in bean leaves at the phase of anthesis are given as example.

\section{CONCLUSIONS}

The bioluminescence method was applied for ATP determination in etiolated wheat germs and bean leaves. The following conclusions were reached.

1. Extraction with $1.5 \mathrm{~N}$ perchloric acid gave similar ATP recovery as did 10 per cent trichloroacetic acid extraction. When Tris-HCl buffer, $\mathrm{pH} 7.4$ was used hot, the amount of ATP was three times lower with wide dispersion of results between the particular experiments.

2. Full, almost 100 per cent recovery of ATP from tissues is obtained in a single extraction.

3. Investigations on the influence of homogenate concentration demonstrated a higher amount of ATP at higher plant tissue concentrations.

4. Lyophilization lowered 5-10 times the ATP level in the tissue. 
5. A similar fall of ATP level was observed when frozen germs were stored at $-28^{\circ} \mathrm{C}$ for $1 \mathrm{~h}$. Storage at $+4^{\circ}$ and $+20^{\circ} \mathrm{C}$ caused smaller losses, the ATP content decreased only by about 30 per cent.

6. The most suitable method of storage of material for later analysis proved freezing of the extracts. ATP values after freezing did not differ from those of determinations in fresh tissue.

7. The measurement error in ATP determination in bean leaves does not exceed 1.5 per cent.

The results point to the necessity of strict observation of the established extraction and analysis conditions resulting from the extreme lability of adenosintriphosphate:

1) performance of all analytical work at low temperature (homogenization in frozen mortar, application of cooled reagents, use of frozen centrifuge test tubes, and centrifuges with cooling);

2) observation of strict extraction and analysis times;

3) use of the same plant tissue concentrations in the homogenate and care to keep the solution for as short as possible a time in diluted state;

4) performance of analyses on fresh and not on lyophylized material; if analysis has to be delayed the material should be stored as frozen extract.

\section{REFERENCES}

A d a m H., 1962. Methoden der Enzymatischen Analyse. Bergmeyer H. U. Verlag Chemie. GmbH s. 539 .

B i eles ki R. L., Y o u n g R. E., 1963. Anal. Biochem. 6: 54.

Ch a s A. M., 1960. [In:] G li ck D. Methods of Biochemical Analysis Interscience, 8: 61 , New York.

Conkel1 M. B., \& Polglas e W. J., 1970. Biochim. Biophys. Acta 223: 439.

Greef J. de., Butler W. L., and Roth T. F., 1971. Plant Physiol. 47: 457.

Dufrensne L. and Gitelm an H. J., 1970. Anal. Biochem., 37: 402-408.

H a l bhurber K. J., Brox D., Stibenz H. J., and Geyer G., 1970. Acta Histochem. 38 (1): 158.

Holm-H a n s en O., \& B oloth Ch. R., 1966. Limnology and Oceanography 11 (4): 510.

Holm Holmsen, J. Holmsen, and A. Bern hardsen, 1966. Anal. Biochem. 17: $456-473$.

Hurlbert R. B., Schmitz H., and Blum A. F., 1965, J. Biol. Chem. 209, 23. Hurwitz J., Heppel L. A., and Horecer B. L., 1957. J. Biol. Chem. 226: 525. J o h n J. B. St., 1970. Anal. Biochem. 37: 409-416.

Kula yev J. S., Bielozierskij A. N., Ostrovskii D. N., 1971. Biokhimia 26 (1): 188.

L a d y gin a M. E., Rubin A. B., 1971. Biofizychieskije mietody w fiziologii rastienii. Izd. „Nauka”, A. N., SSSR.

L a m precht W., Trautschold I., 1962. Metoden der Enzymatischen Analyse Herausgegeben von Hans-Ulrich-Bergmeyer. Verlag Chemie. GMBH, s. 543. 
Le Page G. A., Umbreit W. W., 1948. Methods for the analysis of phosphorylated intermediates in manometric techniques and related methods for the study of tissue metabolism, Burgess Publishing Co.

Li ubimova M. N., Demianovskay a H. S., Fedorovich J. B., 1964. Biokhimia $29,4$.

L in S., C o h en H. P., 1968. Anal. Biochem. 24: 531.

L o erch er L., \& Liverm an J. L., 1964. Plant Physiol. 39 (2): 720.

Lowry O. H., Pas somneau J. V., Has s elberger F. X., and Schulz D. W., 1964. J. Biol. Chem. 239: 18.

M c Elro y W. D., 1974. Proc. nat Acad. Sci. USA, 33: 342.

M c E lr o y W. D., S tr e h l e r B., 1949. Arch. Biochem. 22 (220): 420.

M c D on a ld S. J., \& G u in G., 1969. Plant Physiol. 44: 605.

Miliekhina F. J., Rachliejeva F. F., et al., 1970. Mikrobiol. 39: 722.

Penth B., \& W eig 1 J., 1971. Planta 96: 212.

R o o dy n D. B., 1968. Enzyme Cytology, Acad. Press. London-New York, p. 355. S cha effer G. W., J ohn I. B. S., and Sharpe F. T. J., 1972. Biochim. Biophys. Acta 261 (1): 38.

Sła wi ński J., 1973. Post. Biochem. 19 (3): 484.

S t a n l e y P. E., Wi 11 i a m s S. G., 1969. Anal. Biochem. 29: 381-392.

Strehler B. L., 1962 [In:] Methoden der Enzymatischen Analyse. Bergmeyer H.

U., Verlag Chemie. GmbH. s. 559.

Streh le r B. L., T ot te r J. R., 1952. Arch. Biochem. Biophys. 40, 28.

W o j t a s z e k T., 1959, Zeszyty Naukowe WSR Kraków, 9: 45.

Author's address:

Dr. Agnieszka Barbara and Dr. Stanisław Rożek

Institute of Biology of Crop Plants,

Academy of Agriculture,

Al. Mickiewicza 21; 31-120 Cracow, Poland

Badania metodyczne nad oznaczaniem ATP metoda bioluminiscencji $w$ materiale roślinnym (etiolowane kiełki pszenicy i liście fasoli)

\section{Streszczenie}

W pracy przedstawiono badania nad zastosowaniem metody bioluminiscencji do oznaczeń ATP w ekstraktach z materiału roślinnego; etiolowanych kiełków pszenicy i liści fasoli. Prace metodyczne dotyczyły wyboru sposobu ekstrakcji, oraz utrwalania i przechowywania materiału dla dokonania pomiaru aktualnej, niezmienionej analizą ilości ATP. Emisję światła mierzono przy pomocy aparatury krajowej stanowiącej zasadnicze wyposażenie pracowni izotopowej. Uzyskano następujące wyniki:

1. Ekstrakcja 1,5 $\mathrm{N}$ kwasem nadchlorowym dawala podobne odzyski ATP jak ekstrakcja $10 \%$ kwasem trójchlorooctowym. Natomiast przy stosowaniu buforu Tris-HCl pH 7,4 na gorąco znajdowano trzykrotnie niższe ilości ATP przy dużym rozrzucie wyników między poszczególnymi próbami.

2. Pełne, niemal $100 \%$ wydobycie ATP z ttkanki następuje po jednorazowej ekstrakcji.

3. W badaniach wpływu koncentracji homogenatu wykrywano większe ilości ATP przy większych stężeniach tkanki roślinnej. 
4. Stwierdzono, że liofilizacja spowodowała 5-10-krotne obniżenie poziomu ATP w tkance.

5. Podobny spadek zawartości ATP obserwowano przy przechowywaniu zamrożonych kiełków w temperaturze $-28^{\circ} \mathrm{C}$ nawet przez jedną godzinę; natomiast pozostawienie kiełków przez ten czas w temperaturze $+4^{\circ} \mathrm{i}+20^{\circ} \mathrm{C}$ było mniej szkodliwe, zawartość ATP zmniejszyła się o około $30 \%$.

6. Najlepszym sposobem przechowywania badanego materiału do późniejszych analiz okazało się zamrażanie ekstraktów; oznaczana w ekstraktach po zamrożeniu ilość ATP była na tym samym poziomie co w świeżej tkance.

7. Wyznaczono błąd pomiaru przy pomiarach ATP w liściach fasoli; nie przekracza on $1,5 \%$. 